\title{
Efficacy of intraoperative cell salvage in spine surgery: a meta-analysis
}

\author{
*Jerry Cheriyan, MD, MRCS,, Thomas Cheriyan, MD, ${ }^{2}$ Anterpreet Dua, MD, ${ }^{2}$ \\ Jeffrey A. Goldstein, MD, ${ }^{3}$ Thomas J. Errico, MD, ${ }^{4}$ and Vikas Kumar, MD ${ }^{2}$ \\ 'Department of Surgery, Trauma and Critical Care, Kern Medical Center, Bakersfield, California; 'Department of Anesthesiology, \\ Augusta University, Augusta, Georgia; ${ }^{3}$ Department of Orthopaedic Surgery, NYU Langone Health, New York, New York; and \\ ${ }^{4}$ Department of Orthopedic Surgery, Nicklaus Children's Hospital, Miami, Florida
}

\begin{abstract}
OBJECTIVE Intraoperative cell salvage systems, or cell savers, are widely used for the management of blood loss in patients undergoing spine surgery. However, recent studies report conflicting evidence of their efficacy. The purpose of the meta-analysis was to investigate the efficacy of cell savers in reducing blood transfusion requirements in patients undergoing spine surgery.
\end{abstract}

METHODS Both retrospective and prospective studies that investigated the efficacy of cell savers in reducing transfusion requirements in spine surgery patients when compared with control patients were identified from MEDLINE, Embase, Cochrane Collaboration Library, Google Scholar, and Scopus databases. Outcome data extracted included number of patients receiving allogenic transfusions (transfusion rate); units of allogenic transfusions; postoperative hemoglobin; costs; operative time; and complications. RevMan 5 software was used to perform statistical analyses. A random-effects model was used to calculate pooled odds ratios (with $95 \% \mathrm{Cls}$ ) and weighted mean differences (WMDs $[95 \% \mathrm{CI}])$ for dichotomous and continuous variables, respectively.

RESULTS Eighteen studies with 2815 patients in total were included in the meta-analysis. During spine surgery, the use of intraoperative cell salvage did not reduce the intraoperative (OR $0.66[95 \% \mathrm{Cl} 0.30,1.41])$, postoperative (OR -0.57 $[95 \% \mathrm{Cl} 0.20,1.59])$, or total transfusion (OR $0.92[95 \% \mathrm{Cl} 0.43,1.98])$ rate. There was a reduction in the number of allogenic units transfused intraoperatively by a mean of $0.81(95 \% \mathrm{Cl}-1.15,-0.48)$. However, there were no differences in the number of units transfused postoperatively (WMD $-0.02[95 \% \mathrm{Cl}-0.41,0.38]$ ) or the total units transfused (WMD $0.08[95 \% \mathrm{Cl}-1.06,1.22])$. There were also no differences in operative time (WMD 19.36 [95\% Cl $-2.43,42.15])$ or complications reported (OR $0.79[95 \% \mathrm{Cl} 0.46,1.37])$ between groups. A difference in postoperative hemoglobin (WMD 0.54 $[95 \% \mathrm{Cl} 0.11,0.98])$ between both groups was observed.

CONCLUSIONS Cell saver is efficacious at reducing intraoperative allogenic units transfused. There is no difference in transfusion rates, postoperative units transfused, and the total number of units transfused. Further cost analysis studies are necessary to evaluate the cost-effectiveness of this method of blood conservation.

- CLASSIFICATION OF EVIDENCE Type of question: therapeutic; study design: meta-analysis; strength of recommendation: low.

https://thejns.org/doi/abs/10.3171/2019.12.SPINE19920

KEYWORDS cell saver; cell salvage; spine surgery; blood conservation strategy

$\mathrm{S}$ PINE surgeries, particularly deformity correction surgery, may result in major blood loss due to the long operative times, extensive muscle stripping, and large wound surfaces involved..$^{15}$ Several blood conservation strategies are employed to minimize blood loss and the requirement for allogenic blood transfusions. Though rare, complications associated with allogenic blood transfusions include infection transmission, fluid over- load, hemolytic reactions, and transfusion-related acute lung injury. ${ }^{2}$ In addition, blood products may impair the body's natural immune responses, increasing the risk of postoperative bacterial infection. ${ }^{27}$ Intraoperative cell salvage is a blood loss management strategy in which blood collected from the operative field or postoperatively from suction drain is anticoagulated and centrifuged to isolate red blood cells, which are then washed and filtered before

ABBREVIATIONS AIS = adolescent idiopathic scoliosis; $\mathrm{QALY}=$ quality-adjusted life year; WMD = weighted mean difference

SUBMITTED August 4, 2019. ACCEPTED December 31, 2019.

INCLUDE WHEN CITING Published online April 3, 2020; DOI: 10.3171/2019.12.SPINE19920.

* J.C. and T.C. contributed equally to this work and share first authorship. 


\section{- CLASSIFICATION OF EVIDENCE}

\section{Type of Question Therapeutic \\ Study Design Meta-Analysis \\ Strength of Recommendation Low}

\section{Summary Statement}

This meta-analysis of 15 observational and 3 randomized controlled trials examining the use of intraoperative cell salvage in patients undergoing various spine procedures found no convincing evidence of benefit, and it underscores the need for further well-designed trials.

\section{Classification of Evidence}

Cheriyan and colleagues have undertaken a very timely and comprehensive quantitative systematic review of Englishlanguage studies evaluating the potential benefit of intraoperative cell salvage in patients undergoing spine surgery. The authors identified 18 studies that fulfilled their inclusion and exclusion criteria, and they calculated summary statistics for 9 prespecified primary and secondary outcomes using Cochrane Collaboration software. When performed to exacting standards on an adequate body of evidence, meta-analyses have the potential to provide the most comprehensive and precise evidence-based estimates of the true clinical effect of a given intervention. The key word in the preceding sentence is "precise." The primary contribution of a meta-analysis is to increase the precision (i.e., narrow the confidence interval) of an effect size estimate. Meta-analyses, no matter how well performed, cannot improve the quality of the existing evidence, and they do not create new evidence. Unfortunately, despite good statistical technique, the authors of this paper were not able to provide an answer to their questions about the value of cell salvage technology. They found no benefit of cell salvage for 7 of their 9 prespecified outcomes. In the two outcomes for which a benefit was documented, the improvement in postoperative hemoglobin $(0.54 \mathrm{~g} / \mathrm{dl})$ was statistically significant but of minimal clinical importance, and the reduction in mean units of blood transfused intraoperatively was modest ( 0.81 units), marred by a substantial risk of bias and marginalized by the lack of difference in postoperative or overall units transfused. As mentioned, meta-analyses cannot improve the quality of the evidence they analyze. Cheriyan and colleagues identified 15 observational studies relevant to their question. Because of their retrospective nature and unmasked primary outcome measure (decisions regarding blood transfusion were made by unmasked treating physicians), all 15 of these studies constitute class III evidence at best and more likely class IV evidence using AAN/AANS/ CNS criteria. For similar reasons, the 3 randomized controlled trials also provide only class III evidence. In addition, for 8 of the 9 outcomes analyzed, heterogeneity among included studies was high (this was expressed mathematically by an $\mathrm{I}^{2}$ value $>50 \%$ and qualitatively by the substantial differences among studies in patient populations, interventions, outcome measures, and study methodologies). The other unique threat to reliability that meta-analyses are subject to is publication bias-the selective omission from publication of small, negative trials. Although the authors acknowledge this risk, they do not provide data (from funnel plots or quantitative calculations) regarding the degree of potential publication bias. Because of the limitations of their data, the authors' meta-analysis cannot provide strong guidance for clinicians regarding the usefulness of cell salvage during spine surgery. This does not mean that their meta-analysis is of no value. On the contrary, it emphasizes the paucity of good evidence and should be taken as a call to clinicians to support high-quality randomized trials. Until data from such studies become available, however, practitioners must rely on clinical judgment, unsupported by compelling evidence.

- Michael Glantz, MD
Hershey Medical Center
Hershey, Pennsylvania

reinfusion. This method has been shown to salvage $60 \%-$ $80 \%$ of red cells lost during surgery. ${ }^{5}$ Early studies on efficacy ${ }^{25,26}$ found this method to be beneficial for children and young adults undergoing spinal surgery. Furthermore, the authors found cell saver to be more cost-effective than allogenic transfusions in patients with operative blood loss greater than $2000 \mathrm{ml}$, due to the high costs of these transfusions. More recent studies, however, have reported conflicting evidence on the efficacy of cell savers and the costeffectiveness in reducing blood transfusion requirements in spine surgery. The purpose of this meta-analysis was to investigate the efficacy of cell savers in reducing allogenic transfusion rates in patients undergoing spine surgery. A review of cost analysis studies was also performed.

\section{Methods}

The meta-analysis was performed according to the PRISMA requirements for quality reporting of systematic reviews and meta-analyses. ${ }^{19}$

\section{Electronic Literature Search}

We conducted a systematic review of the published literature through January 2019 on the efficacy of cell savers in spine surgery. Our results were limited to studies published in the English language over the past 30 years. Databases searched included MEDLINE, Embase, Cochrane Collaboration Library, Google Scholar, and Scopus. In addition, we examined reference lists of included articles for any studies missed on our initial search. Search terms included "intraoperative cell salvage," "cell saver," and "spine."

\section{Study Selection}

We performed a systematic review of all prospective and observational studies, assessing the efficacy of cell savers compared with no cell savers on the transfusion requirements in patients undergoing spine surgery. We included all age groups and all spinal procedures, excluding spinal tumor and trauma surgery. Studies were excluded if they did not have a control cohort. In addition, we excluded review articles, case reports, and case series. Eligible publications were selected by two independent reviewers, 
and any disagreement was settled after discussion with a third reviewer.

\section{Quality Assessment}

Assessments of quality were done for each published study by two independent reviewers. Assessment of nonrandomized studies was done using a modified NewcastleOttawa scale. Using this assessment each study is judged based on 9 items in 3 different categories: selection of study groups (4 items), comparability of study groups (2 items), and ascertainment of outcomes of interest (3 items). Points are awarded in each section, with a maximum of 9 points awarded for lowest-bias observational studies. Bias of study was categorized as high (0-3), medium (4-6), or low (6-8). Prospective studies were assessed as outlined by Jadad et al. ${ }^{13}$ Included studies were graded in 3 categories: randomization, comparability, and outcome. Studies graded with a score of $0-1,2-3$, or 4-5 (out of a maximum score of 5) were considered to be of high, medium, or low bias, respectively. Studies graded as having a high risk of bias according to either scale were discussed among all reviewers to decide on inclusion.

\section{Data Extraction}

Each study was thoroughly reviewed independently by two reviewers to ensure complete and accurate data extraction. General study characteristics extracted were as follows: study design and purpose, study group size, mean age, sex distribution, geographical location, inclusion/exclusion criteria, and publication date. Primary outcomes extracted included number of patients who received allogenic transfusions (transfusion rate), units or volume of allogenic transfusions, and postoperative hemoglobin concentration. Secondary outcomes of interest included operative time and transfusion-related complications, such as immunological reactions, hemodynamic overload, transfusion-related acute lung injury, and postoperative bacterial infection. In cases of insufficient data, the corresponding author was contacted for clarification and information.

\section{Statistical Analysis}

Meta-analysis was performed using Review Manager Software 5.0 (Cochrane Community). Weighted mean differences (WMDs) with $95 \%$ CIs and pooled odds ratios with $95 \%$ CIs were used to assess effect size of continuous data (e.g., volume of blood loss, hemoglobin concentration) and dichotomous data (e.g., number of transfusions, incidence of complications), respectively. A random-effects model was used in all analyses. Publication bias was assessed by funnel plot and $\mathrm{I}^{2}>$ statistic for heterogeneity. An $\mathrm{I}^{2}>50 \%$ was considered suggestive of substantial heterogeneity.

\section{Results \\ Study Selection}

Our search resulted in a total of 9550 citations. After screening by title, abstract, and entire article, 18 studies were identified that met all inclusion criteria and had us-

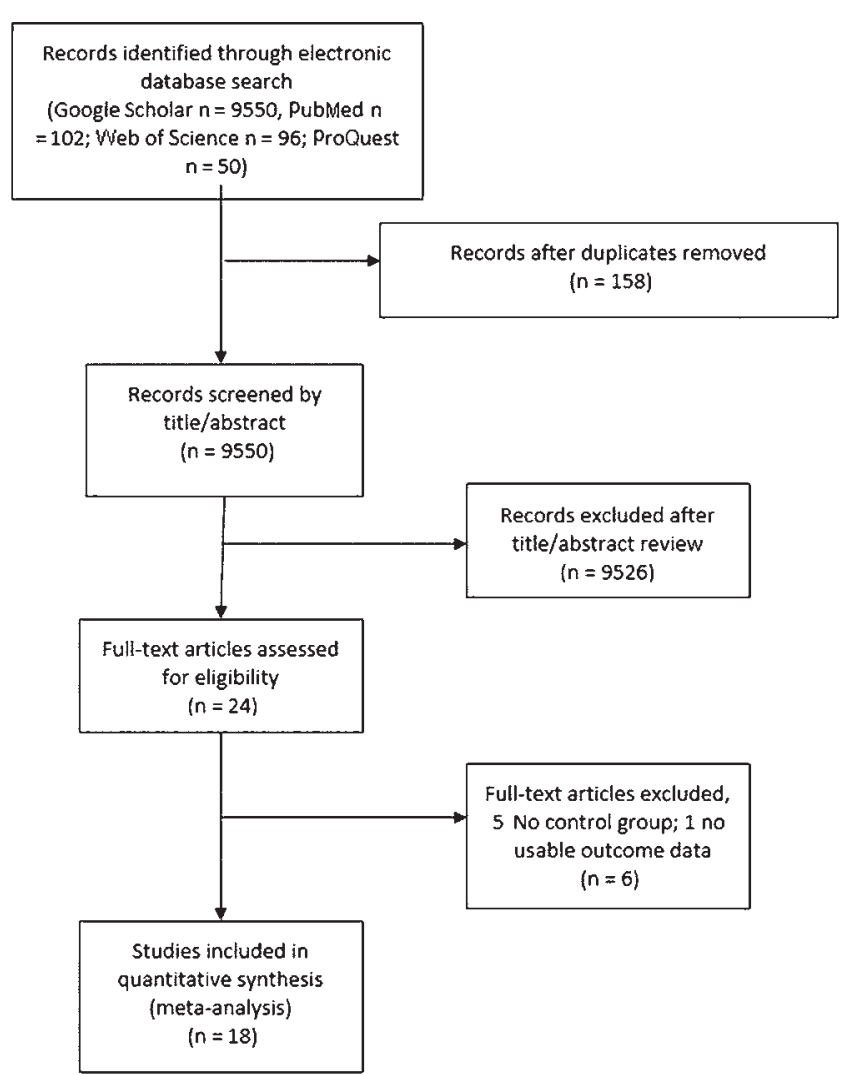

FIG. 1. PRISMA flow diagram of study selection.

able data. Figure 1 shows the method of study selection and inclusion. Study characteristics of included studies are described in Tables 1 and 2.

\section{Quality Assessment}

The modified Newcastle-Ottawa scale score of retrospective studies varied between 7 and 8 (low bias) (Table 3 ). The two prospective studies had a Jadad score of 0 and 2 (high and medium bias, respectively) (Table 3). Sample size varied between 42 and 680 patients, with a mean of 156 patients in each study.

\section{Effect on Transfusion Rate}

Thirteen ${ }^{3,4,6,8,11,12,14,16,18,21-23,30}$ studies $(\mathrm{n}=2118$; cell saver/control $=1078 / 1040)$ reported on the number of patients transfused in each group. Eight studies ${ }^{4,6,8,11,14,21-23}$ (n $=1205$; cell saver/control $=444 / 761$ ) reported data on intraoperative transfusion rate. The cell saver group did not show a significant difference in intraoperative transfusion rates (OR 0.66 [95\% CI 0.30, 1.41]; $\mathrm{p}=0.28 ; \mathrm{I}^{2}=81 \%$ ). There was also no difference in the postoperative transfusion rates among the 5 studies $^{8,14,18,21,22}(\mathrm{n}=920$; cell saver/ control $=364 / 556)$ that reported on outcomes (OR 0.57 $[95 \%$ CI $\left.0.20,1.59] ; \mathrm{p}=0.28 ; \mathrm{I}^{2}=79 \%\right)$. Similarly, in the 7 studies $^{3,4,6,12,16,22,27}(\mathrm{n}=920$; cell saver/control $=364 / 556)$ that reported on total transfusion rates, there was no significant difference between cell saver and control cohorts (OR 0.92 [95\% CI 0.43, 1.98]; $\mathrm{p}=0.84 ; \mathrm{I}^{2}=83 \%$ ) (Fig. 2). 
TABLE 1. Assessment study of bias using Newcastle-Ottawa scoring for retrospective studies

\begin{tabular}{lccccc}
\hline & \multicolumn{1}{c}{ Criteria for Study Bias in Retrospective Studies } & & \\
\cline { 2 - 4 } \multicolumn{1}{c}{ Authors \& Year } & Selection & Comparability & Outcome & Total Score & Bias Assessment \\
\hline Akgül et al., 2014 & 4 & 1 & 3 & 8 & Low \\
\hline Behrman \& Keim, 1992 & 3 & 1 & 3 & 7 & Low \\
\hline Bowen et al., 2010 & 4 & 1 & 3 & 8 & Low \\
\hline Canan et al., 2013 & 4 & 1 & 3 & 8 & Low \\
\hline Choi et al., 2019 & 4 & 1 & 3 & 8 & Low \\
\hline Ersen et al., 2012 & 4 & 1 & 3 & 8 & Low \\
\hline Gause et al., 2008 & 3 & 1 & 3 & 7 & Low \\
\hline Gum et al., 2017 & 4 & 1 & 3 & 8 & Low \\
\hline Kelly et al., 2015 & 4 & 0 & 3 & 7 & Low \\
\hline Miao et al., 2014 & 4 & 1 & 3 & 8 & Low \\
\hline Mirza et al., 2009 & 3 & 1 & 3 & 7 & Low \\
\hline Oliveira et al., 2017 & 4 & 1 & 3 & 8 & Low \\
\hline Owens et al., 2013 & 3 & 1 & 3 & 7 & Low \\
\hline Reitman et al., 2004 & 3 & 1 & 3 & 7 & Low \\
\hline Weiss et al., 2007 & 3 & 1 & 3 & 7 & Low \\
\hline
\end{tabular}

\section{Effect on Units Transfused}

Six studies, ${ }^{6,7,10,16,17,21}$ which included 515 patients (cell saver/control $=301 / 214$ ) reported on the mean units of blood products transfused intraoperatively. The cell saver usage reduced the number of units transfused intraoperatively by an average of 0.81 units $(95 \% \mathrm{CI}-1.15,-0.48$; $\mathrm{p}<0.01$ ) when compared to controls (Fig. 3A). However,

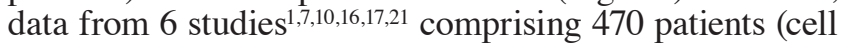
saver/control $=269 / 201$ ) did not show a significant difference in the mean number of units transfused postoperatively (WMD -0.02 [95\% CI $-0.41,0.38] ; \mathrm{p}=0.93$ ) (Fig. 3B). There was also no difference in total units transfused (WMD 0.08 [95\% CI -1.06, 1.22]; $\mathrm{p}=0.89$ ) between the two groups in the 5 studies $1,8,10,17,21$ that reported on these outcomes (Fig. 3C). There was a statistically significant and modest difference in postoperative hemoglobin by an average WMD of 0.54 (95\% CI $0.11,0.98 ; \mathrm{p}=0.01)$ between the cell saver and control groups (5 studies, ${ }^{1,4,8,16,21}$ $\mathrm{n}=334)$ (Fig. 4).

\section{Effect on Operative Time and Complications}

Eight studies ${ }^{1,4,6-8,14,16,21}(\mathrm{n}=1033$; cell saver/control $=$

TABLE 2. Assessment of study bias using Jadad scoring for prospective studies

\begin{tabular}{|c|c|c|c|c|c|}
\hline \multirow{2}{*}{$\begin{array}{l}\text { Authors } \\
\text { \& Year }\end{array}$} & \multicolumn{3}{|c|}{$\begin{array}{c}\text { Criteria for Study Bias in } \\
\text { Prospective Studies }\end{array}$} & \multirow{2}{*}{$\begin{array}{l}\text { Total } \\
\text { Score }\end{array}$} & \multirow{2}{*}{$\begin{array}{c}\text { Bias } \\
\text { Assessment }\end{array}$} \\
\hline & Randomization & Blinding & Dropout & & \\
\hline $\begin{array}{l}\text { Djurasovic } \\
\text { et al., } 2018\end{array}$ & 1 & 0 & 1 & 2 & Medium \\
\hline $\begin{array}{l}\text { Liang et } \\
\text { al., } 2015\end{array}$ & 2 & 0 & 0 & 2 & Medium \\
\hline $\begin{array}{l}\text { Savvidou } \\
\text { et al., } 2009\end{array}$ & 0 & 0 & 0 & 0 & High \\
\hline
\end{tabular}

394/639) reported on the operative time between the cell saver and control groups (WMD -19.36 [95\% CI -2.43, 41.15]; $p=0.08$ ) (Fig. 5A). There was no difference in complications (OR -0.78 [95\% CI 0.36, 1.68]; $p=0.57$ ) reported in 5 studies ${ }^{6,7,14,16,23}(\mathrm{n}=957$; cell saver/control $=$ 369/588) (Fig. 5B).

\section{Discussion}

This meta-analysis supports modest efficacy of intraoperative cell salvage systems in reducing intraoperative units transfused in patients undergoing spine surgery. No significant effects were observed for any other primary outcomes, including intraoperative, postoperative, and total transfusion rates or postoperative and total units transfused. There was a small benefit with respect to postoperative hemoglobin. However, there was no difference in any secondary outcomes, including operative time and the incidence of complications.

To our knowledge, this is the first meta-analysis to investigate the efficacy of cell savers in reducing the transfusion burden in patients undergoing spine surgery. A 2010 systematic review by Elgafy et al. ${ }^{9}$ reported that there was little evidence to support its cost or effective use during routine spine surgery. This recommendation was based on a review of 3 retrospective studies of poor methodological quality.

One would expect cell savers to reduce the units transfused, since much of the patient's blood loss is returned intraoperatively, and our results support this intuition. However, we did not observe any reduction in transfusion rates in the cell saver group, leaving both patient cohorts equally exposed to the potential dangers and complications associated with allogenic blood transfusions. However, the advantage of a reduction in units transfused may improve patient outcomes by decreasing the risk of the dose-dependent complications of transfusions, such as hemodynamic overload, and the odds of transmitting blood- 
TABLE 3. Characteristics of included studies

\begin{tabular}{|c|c|c|c|c|c|}
\hline $\begin{array}{l}\text { Authors } \\
\& \text { Year }\end{array}$ & Country & $\begin{array}{l}\text { Sample Size } \\
\text { (cell saver/ } \\
\text { control) }\end{array}$ & Surgery & Transfusion Criteria & Limitations \\
\hline Akgül et al., 2014 & Turkey & $16 / 17$ & Posterior spinal fusion & $\begin{array}{l}\mathrm{Hb}<8 \mathrm{mg} / \mathrm{dl} \text { w/ clinical findings } \\
\text { of anemia; absolute }<7 \mathrm{mg} / \mathrm{dl}\end{array}$ & Small sample size \\
\hline $\begin{array}{l}\text { Behrman \& Keim, } \\
1992 \text { (i) }\end{array}$ & USA & $25 / 25$ & Posterior spinal fusion & Surgeon decision & Small sample size; no transfusion guidelines \\
\hline $\begin{array}{l}\text { Behrman \& Keim, } \\
1992 \text { (ii) }\end{array}$ & USA & $25 / 25$ & $\begin{array}{l}\text { Posterior spinal decom- } \\
\text { pression and fusion }\end{array}$ & Surgeon decision & Small sample size; no transfusion guidelines \\
\hline $\begin{array}{l}\text { Bowen et al., } \\
2010\end{array}$ & USA & $33 / 21$ & Posterior spinal fusion & $\begin{array}{l}\mathrm{Hb}<8 \mathrm{mg} / \mathrm{dl} \mathrm{w} / \text { clinical findings } \\
\quad \text { of anemia; absolute }<7 \mathrm{mg} / \mathrm{dl}\end{array}$ & $\begin{array}{l}\text { Small control group; different between- } \\
\text { group surgical blood loss rates }\end{array}$ \\
\hline $\begin{array}{l}\text { Canan et al., } \\
2013\end{array}$ & USA & $48 / 30$ & $\begin{array}{l}\text { Posterior spinal decom- } \\
\text { pression and fusion }\end{array}$ & $\mathrm{Hb}<8 \mathrm{mg} / \mathrm{dl} \mathrm{w} /$ clinical findings & $\begin{array}{l}\text { Different between-group surgical blood loss } \\
\text { rates }\end{array}$ \\
\hline Choi et al., 2019 & Korea & $81 / 32$ & $\begin{array}{l}\geq 5 \text {-level posterior } \\
\text { spinal fusion }\end{array}$ & $\begin{array}{l}\mathrm{Hb}<7 \mathrm{mg} / \mathrm{dl} \text { or if anemic symp- } \\
\text { toms; surgeon decision }\end{array}$ & Small sample size \\
\hline $\begin{array}{l}\text { Djurasovic et al., } \\
2018\end{array}$ & USA & $48 / 47$ & $\begin{array}{l}\text { 2- or 3-level posterior } \\
\text { spinal fusion }\end{array}$ & $\begin{array}{l}\mathrm{Hb}<7 \mathrm{mg} / \mathrm{dl} \text { or if anemic symp- } \\
\quad \text { toms; surgeon decision }\end{array}$ & $\begin{array}{l}\text { Small sample size; no postoperative transfu- } \\
\text { sion guidelines }\end{array}$ \\
\hline Ersen et al., 2012 & Turkey & $23 / 22$ & Posterior spinal fusion & $\begin{array}{l}\mathrm{Hb}<8 \mathrm{mg} / \mathrm{dl} \mathrm{w} / \text { clinical findings } \\
\text { of anemia; absolute }<7 \mathrm{mg} / \mathrm{dl}\end{array}$ & Small sample size \\
\hline $\begin{array}{l}\text { Gause et al., } \\
2008\end{array}$ & USA & $141 / 47$ & $\begin{array}{l}\text { Posterior spinal decom- } \\
\text { pression and fusion }\end{array}$ & $\begin{array}{l}\mathrm{Hb}<7 \mathrm{mg} / \mathrm{dl} ; \mathrm{Hct}<21 \text {; or symp- } \\
\quad \text { tomatic anemia }\end{array}$ & Selection bias \\
\hline Gum et al., 2017 & USA & $427 / 253$ & $\begin{array}{l}\text { Posterior, anterior-pos- } \\
\text { terior spinal fusion }\end{array}$ & Surgeon decision & $\begin{array}{l}\text { Intercenter variability; no transfusion guide- } \\
\text { line; preoperative } \mathrm{Hb} \text { data unavailable }\end{array}$ \\
\hline Kelly et al., 2015 & USA & $86 / 422$ & $\begin{array}{l}\leq 3 \text {-level laminectomy } \\
\text { and fusion }\end{array}$ & No guideline & Small sample size in cell saver group \\
\hline Liang et al., 2015 & China & $55 / 55$ & Posterior spinal fusion & $\begin{array}{l}\mathrm{Hb}<7 \mathrm{mg} / \mathrm{dl} \text { or symptomatic } \\
\text { anemia }\end{array}$ & Small sample size \\
\hline Miao et al., 2014 & China & $67 / 180$ & Posterior spinal fusion & $\begin{array}{l}\mathrm{Hb}<8 \mathrm{mg} / \mathrm{dl} \mathrm{w} / \text { clinical findings } \\
\text { of anemia; absolute }<7 \mathrm{mg} / \mathrm{dl}\end{array}$ & $\begin{array}{l}\text { Different between-group surgical blood loss } \\
\text { rates }\end{array}$ \\
\hline Mirza et al., 2009 & UK & $104 / 33$ & Posterior spinal fusion & $>1$ L operative loss; $\mathrm{Hb}<7$ mg/dl & Small control group \\
\hline $\begin{array}{l}\text { Oliveira et al., } \\
2017\end{array}$ & Brazil & $27 / 15$ & Posterior spinal fusion & $\begin{array}{l}\mathrm{Hb}<8 \mathrm{mg} / \mathrm{dl} \mathrm{w} / \text { clinical findings } \\
\text { of anemia; or } \mathrm{Hb}<7 \mathrm{mg} / \mathrm{dl}\end{array}$ & Small sample size \\
\hline $\begin{array}{l}\text { Owens et al., } \\
2013\end{array}$ & USA & $99 / 39$ & Posterior spinal fusion & $\begin{array}{l}\mathrm{Hb}<7 \mathrm{mg} / \mathrm{dl} \text {; symptomatic ane- } \\
\quad \text { mia; or preexisting cardiopul- } \\
\text { monary disease }\end{array}$ & $\begin{array}{l}\text { Different between-group surgical blood loss } \\
\text { rates }\end{array}$ \\
\hline $\begin{array}{l}\text { Reitman et al., } \\
2004\end{array}$ & USA & $56 / 46$ & Posterior spinal fusion & Not mentioned & $\begin{array}{l}\text { Included different procedures; no transfu- } \\
\text { sion guidelines }\end{array}$ \\
\hline $\begin{array}{l}\text { Savvidou et al., } \\
2009\end{array}$ & Greece & $25 / 25$ & Posterior spinal fusion & $\begin{array}{l}\mathrm{Hb}<7 \mathrm{mg} / \mathrm{dl} ; \mathrm{Hct}<21 ; \text { or symp- } \\
\quad \text { tomatic anemia }\end{array}$ & Included different procedures \\
\hline Weiss et al., 2007 & USA & $58 / 37$ & Posterior spinal fusion & Surgeon decision & No transfusion guidelines \\
\hline
\end{tabular}

$\mathrm{Hb}=$ hemoglobin; $\mathrm{Hct}=$ hematocrit .

borne infections. Numerous studies have also shown dosedependent increases in morbidity, mortality, and cost with each unit of packed red blood cells that is transfused. ${ }^{20}$

Among the 7 studies that included adolescent idiopathic scoliosis (AIS) patients, 1 study $^{4}$ reported on intraoperative transfusion rate, 1 study $^{18}$ on postoperative transfusion rate, and 3 studies $7,8,9$ on total transfusion rate data. The mean number of levels fused among these studies varied from 9.8 to 12.9. There was no significant difference in total transfusion rate $(\mathrm{OR}=-0.39[0.13,1.15] ; \mathrm{p}=0.03)$ between cell saver and non-cell saver groups in the AIS cohort. In the AIS cohort, there was a decrease in number of allogenic units transfused intraoperatively by $0.70(95 \%$ CI 1.22, 0.19; $\mathrm{p}=0.04, \chi^{2}=6.34, \mathrm{I}^{2}=68 \%$ ) among the 3 studies that reported on the outcome. ${ }^{11,13,14}$ However, there was no difference in the postoperative allogenic units transfused (OR 0.10 [95\% CI $-0.38,0.58] ; \mathrm{p}=0.005$ ) or total units transfused $(\mathrm{OR}=0.93[95 \% \mathrm{CI}-0.40,2.26] ; \mathrm{p}$ $=0.005)$. There were 4 studies on patients with adult degenerative spine disease. However, the only outcome that was consistently reported among them was intraoperative transfusion rate. There was no difference in this outcome between the cell saver and non-cell saver groups (OR 1.19 [95\% CI 0.41, 3.39]; $\mathrm{p}<0.01 ; \mathrm{I}^{2}=84 \%$ ). 


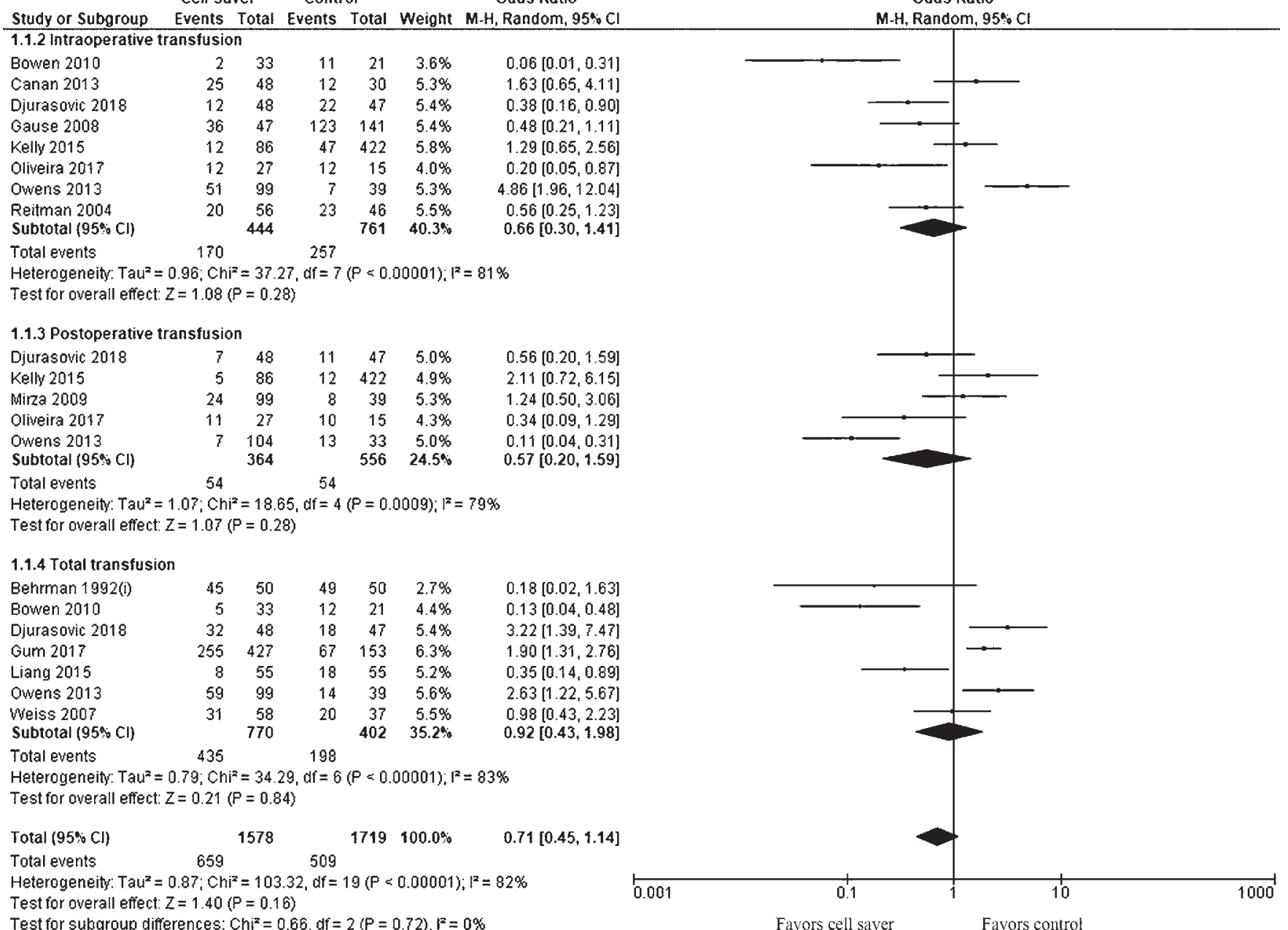

FIG. 2. Forest plots showing the effect of cell savers on transfusion rates. $M-H=$ Mantel-Haenszel.

Given that the average reduction in intraoperative allogenic units transfused is less than 1 unit when using the cell saver, this beneficial effect must be balanced against the increased costs in order to make an appropriate recommendation. To better understand the implications of costs, we reviewed 4 studies that investigated the cost-effectiveness of cell saver usage in spine surgery. In a retrospective review of 102 consecutive cases of posterolateral fusion with instrumentation at one institution, Reitman et al. ${ }^{23}$ reported an average charge of $\$ 512$ per patient for the cell saver and $\$ 270$ per patient for autotransfusion in the control group. The cost of transfusion for allogenic blood was $\$ 250$. The authors attributed the higher cost of cell saver usage to the fixed cost of the operation, regardless of the amount of blood salvaged and replaced. Due to higher costs for the cell saver, the authors recommended its use only in cases in which anticipated blood loss is extremely high and the expected charge for allogenic transfusion may equal or exceed the fixed cost of using a cell saver, which carries no marginal cost of use.

Savvidou et al. ${ }^{24}$ evaluated the efficacy and cost-effectiveness of cell saver usage at one European institution. They estimated significantly lower costs associated with transfusion in the cell saver group than the non-cell saver group ( $€ 995 \pm € 447 \mathrm{vs} € 1220 \pm € 269$ per patient). In addition, the authors posited that the potential costs associated with transfusion-related complications, in the patients who received allogenic transfusions, would increase to a greater degree the overall medical charges in the non-cell saver group. However, they did not take into account the cost of the cell saver in the analysis. Miao et al. ${ }^{17}$ retrospectively reviewed the total costs of blood products in a Chinese sample of school-aged children undergoing posterolateral fusion with instrumentation. They reported no significant difference between total costs of the perioperative transfusion of all blood products before and after adjusting for the lower cost of allogenic blood products in China, compared with the US, and therefore determined that the use of a cell saver was not a cost-effective practice. It is important to note that it is difficult to calculate costs associated with the avoidance of the rare complications associated with allogenic transfusions. From a retrospective chart review at a single institution, Canan et al. ${ }^{6}$ performed a robust costeffective analysis to determine the incremental cost-effectiveness ratio of cell saver usage for single-level posterior lumbar decompression and fusion. The authors estimated 


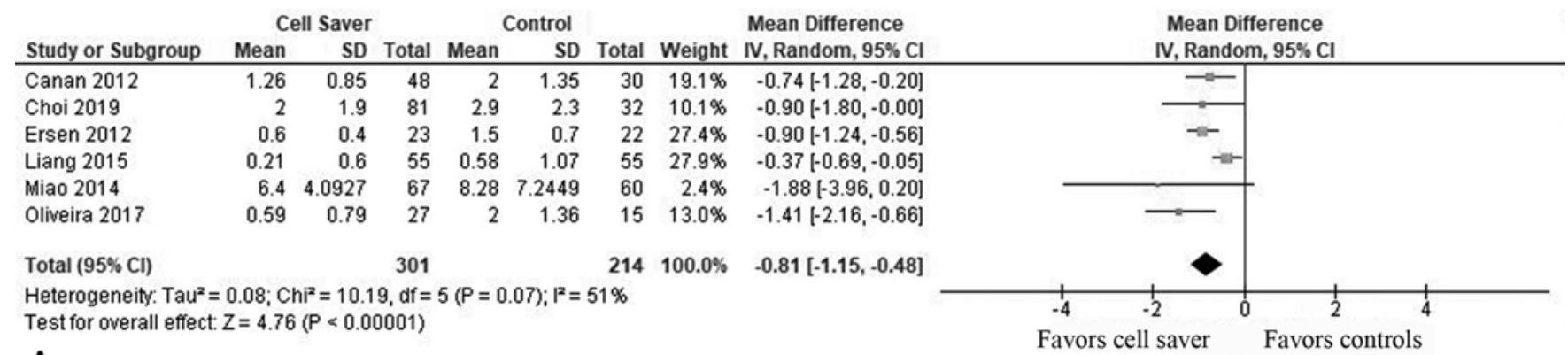

A

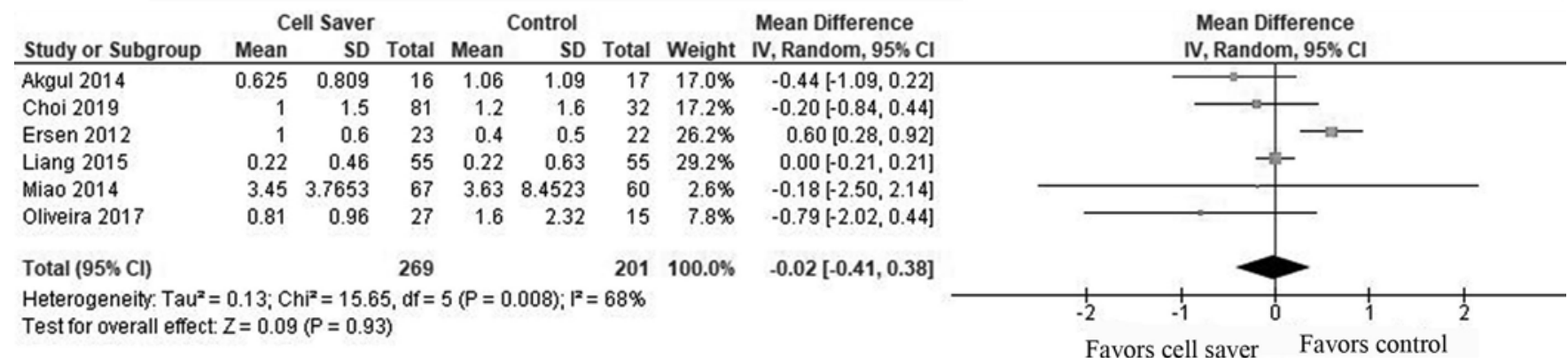

B

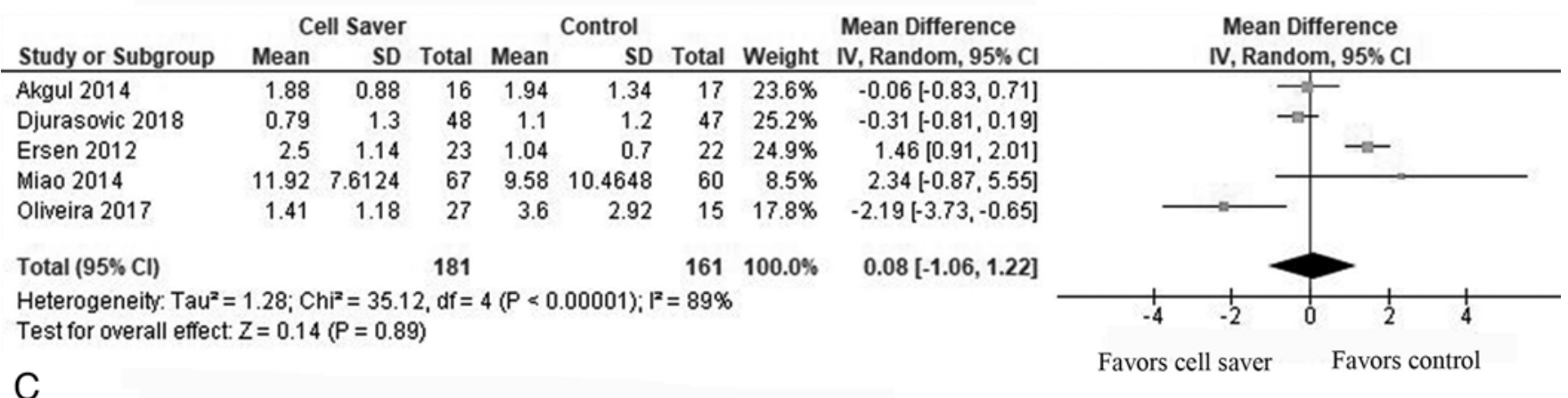

FIG. 3. Forest plots showing the effect of cell savers on intraoperative units transfused (A), postoperative units transfused (B), and total units transfused (C). IV = inverse variant.

the total costs of blood products were $\$ 1012$ for surgeries without a cell saver versus $\$ 1133$ for surgeries with a cell saver available but not used and $\$ 3018$ for surgeries with a cell saver used, for an average of $\$ 1736$ when the cell saver was available. The incremental cost-effectiveness ratio was initially calculated as $\$ 55,538.46 /$ transfusion averted, but after converting the denominator to quality-adjusted life years (QALYs) gained (0.01 QALY gained/transfusion

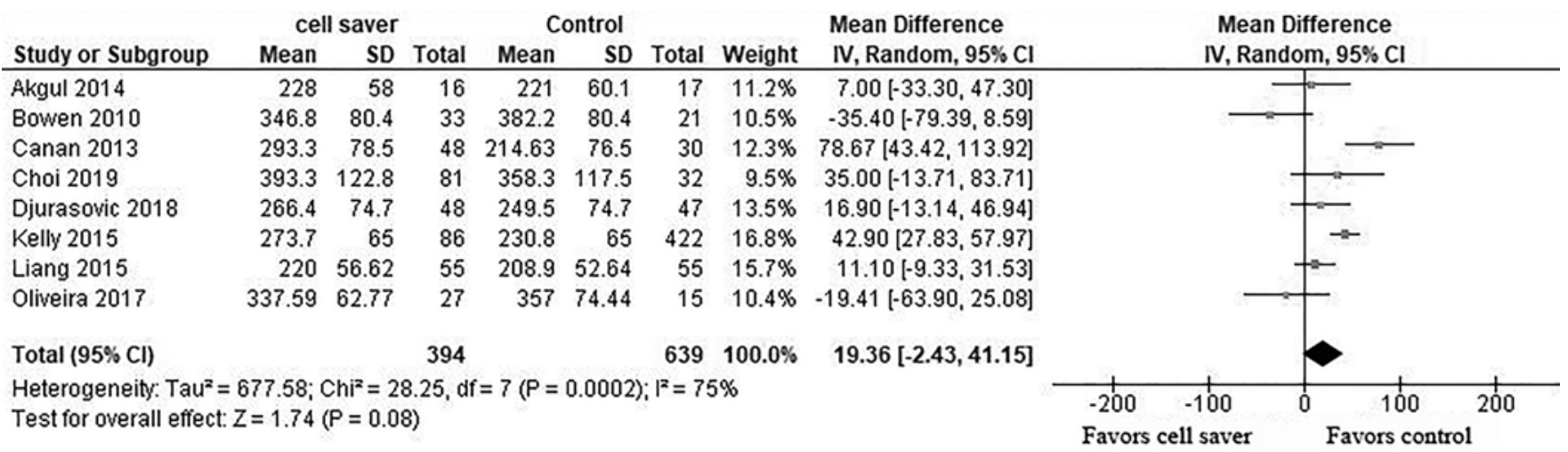

FIG. 4. Forest plot showing the effect of cell savers on postoperative hemoglobin. 


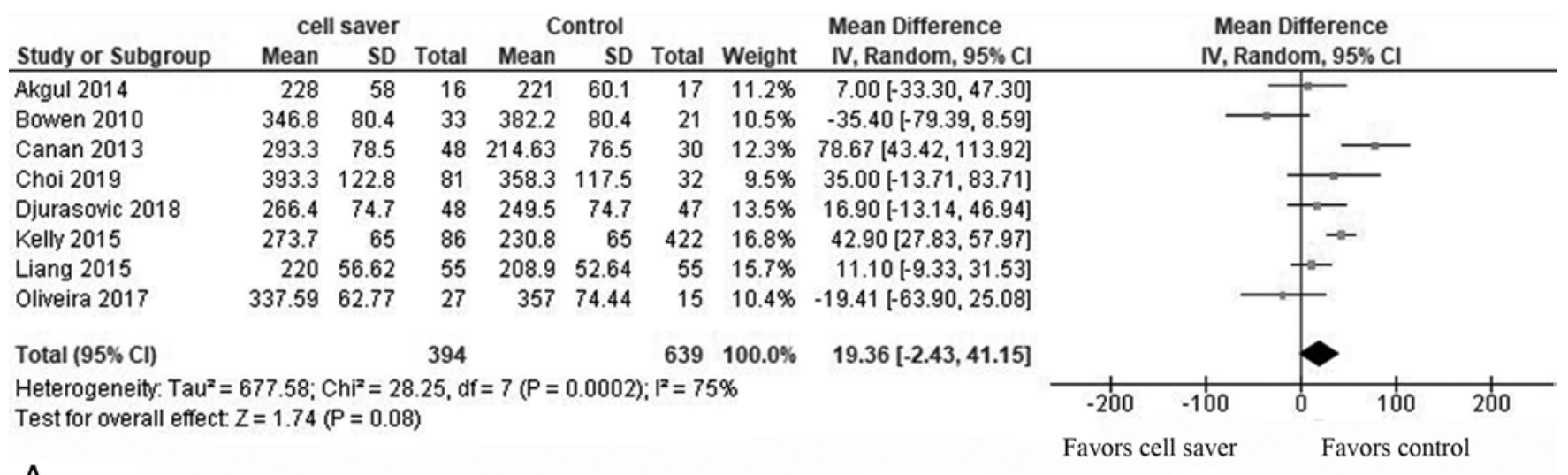

A

\begin{tabular}{|c|c|c|c|c|c|c|c|c|c|c|}
\hline \multirow[b]{2}{*}{ Study or Subgroup } & \multicolumn{2}{|c|}{ Cell saver } & \multicolumn{2}{|c|}{ Control } & \multirow[b]{2}{*}{ Weight } & \multirow{2}{*}{$\begin{array}{c}\text { Odds Ratio } \\
\text { M-H, Fixed, } 95 \% \mathrm{Cl}\end{array}$} & \multirow{2}{*}{\multicolumn{4}{|c|}{$\begin{array}{c}\text { Odds Ratio } \\
\text { M-H, Fixed, } 95 \% \mathrm{Cl}\end{array}$}} \\
\hline & Events & Total & Events & Total & & & & & & \\
\hline Canan 2013 & 2 & 48 & 3 & 30 & $12.1 \%$ & $0.39[0.06,2.49]$ & & & & \\
\hline Choi 2019 & 15 & 81 & 5 & 32 & $20.0 \%$ & $1.23[0.41,3.71]$ & & & & \\
\hline Kelly 2015 & 3 & 86 & 27 & 422 & $30.2 \%$ & $0.53[0.16,1.78]$ & & & & \\
\hline Liang 2015 & 4 & 55 & 7 & 65 & $20.4 \%$ & $0.65[0.18,2.35]$ & & & & \\
\hline Owens 2013 & 12 & 99 & 4 & 39 & $17.3 \%$ & $1.21[0.36,4.00]$ & & & & \\
\hline Total $(95 \% \mathrm{Cl})$ & & 369 & & 588 & $100.0 \%$ & $0.79[0.46,1.37]$ & & & & \\
\hline Total events & 36 & & 46 & & & & & & & \\
\hline $\begin{array}{l}\text { Heterogeneity. } \mathrm{Chi}^{2}= \\
\text { Test for overall effect } \\
R\end{array}$ & $\begin{array}{l}2.15, d f= \\
Z=0.83\end{array}$ & $\begin{array}{l}4(P= \\
P=0.4\end{array}$ & $\begin{array}{l}0.71) ;\left.\right|^{2}= \\
\text { 1) }\end{array}$ & $=0 \%$ & & & 0.01 & $\begin{array}{c}0.1 \\
\text { Favors cell saver }\end{array}$ & $\begin{array}{r}10 \\
\text { Favors control }\end{array}$ & 100 \\
\hline
\end{tabular}

FIG. 5. Forest plots showing the effect of cell saver on operative time (A) and complications (B).

averted), the cost increased to $\$ 5,553,846 / \mathrm{QALY}$ gained, which is in excess of the advocated willingness-to-pay threshold of \$100,000/QALY and therefore not a cost-effective practice.

The limitations of this meta-analysis were the significant heterogeneity in study design and reported outcome measures. The majority of the outcome data were contributed by AIS studies, and thus the applicability of the results across spine surgery is questionable. Only 3 studies reported specifically on the type of blood product transfused. Furthermore, the majority of studies included in the present analysis were observational and provided lower levels of evidence. Due to the paucity of studies, separate subanalyses on prospective and retrospective studies were not performed. Interpretation of results should take into account the sample size and quality of studies contributing that outcome, since only select studies contributed to each outcome measure.

Future research in this area should be aimed at performing randomized controlled trials to assess the reduction in transfusion rates associated with the use of cell savers in spine surgery. In addition, there is conflicting evidence on the cost-effectiveness of cell savers in spine surgery, with two studies reporting that it is not a cost-effective practice and two reporting the opposite. Therefore, more costeffective analyses are needed to determine the economic benefit of the use of cell saver.

\section{Conclusions}

This meta-analysis supports modest efficacy of intra- operative cell salvage systems in reducing intraoperative units transfused in patients undergoing spine surgery. However, no significant effects were observed with respect to intraoperative, postoperative, and total transfusion rates or postoperative and total units transfused. Further cost analysis studies are necessary to evaluate the cost-effectiveness of cell saver in spine surgery.

\section{References}

1. Akgül T, Dikici F, Ekinci M, Buget M, Polat G, Sar C: The efficacy of cell saver method in the surgical treatment of adolescent idiopathic scoliosis. Acta Orthop Traumatol Turc 48:303-306, 2014

2. Alter HJ, Klein HG: The hazards of blood transfusion in historical perspective. Blood 112:2617-2626, 2008

3. Behrman MJ, Keim HA: Perioperative red blood cell salvage in spine surgery. A prospective analysis. Clin Orthop Relat Res (278):51-57, 1992

4. Bowen RE, Gardner S, Scaduto AA, Eagan M, Beckstead J: Efficacy of intraoperative cell salvage systems in pediatric idiopathic scoliosis patients undergoing posterior spinal fusion with segmental spinal instrumentation. Spine (Phila Pa 1976) 35:246-251, 2010

5. Brookfield KF, Brown MD, Henriques SM, Buttacavoli FA, Seitz AP: Allogeneic transfusion after predonation of blood for elective spine surgery. Clin Orthop Relat Res 466:19491953,2008

6. Canan CE, Myers JA, Owens RK, Crawford CH III, Djurasovic $\mathrm{M}$, Burke LO, et al: Blood salvage produces higher total blood product costs in single-level lumbar spine surgery. Spine (Phila Pa 1976) 38:703-708, 2013

7. Choi HY, Hyun SJ, Kim KJ, Jahng TA, Kim HJ: Clinical 
efficacy of intra-operative cell salvage system in major spinal deformity surgery. J Korean Neurosurg Soc 62:53-60, 2019

8. Djurasovic M, McGraw KE, Bratcher K, Crawford CH, Dimar JR, Puno RM, et al: Randomized trial of Cell Saver in 2- to 3-level lumbar instrumented posterior fusions. J Neurosurg Spine 29:582-587, 2018

9. Elgafy H, Bransford RJ, McGuire RA, Dettori JR, Fischer D: Blood loss in major spine surgery: are there effective measures to decrease massive hemorrhage in major spine fusion surgery? Spine (Phila Pa 1976) 35 (9 Suppl):S47-S56, 2010

10. Ersen O, Ekıncı S, Bilgic S, Kose O, Oguz E, Sehırlıglu A: Posterior spinal fusion in adolescent idiopathic scoliosis with or without intraoperative cell salvage system: a retrospective comparison. Musculoskelet Surg 96:107-110, 2012

11. Gause PR, Siska PA, Westrick ER, Zavatsky J, Irrgang JJ, Kang JD: Efficacy of intraoperative cell saver in decreasing postoperative blood transfusions in instrumented posterior lumbar fusion patients. Spine (Phila Pa 1976) 33:571-575, 2008

12. Gum JL, Carreon LY, Kelly MP, Hostin R, Robinson C, Burton DC, et al: Cell saver for adult spinal deformity surgery reduces cost. Spine Deform 5:272-276, 2017

13. Jadad AR, Moore RA, Carroll D, Jenkinson C, Reynolds DJ, Gavaghan DJ, et al: Assessing the quality of reports of randomized clinical trials: is blinding necessary? Control Clin Trials 17:1-12, 1996

14. Kelly PD, Parker SL, Mendenhall SK, Bible JE, Sivasubramaniam P, Shau DN, et al: Cost-effectiveness of cell saver in short-segment lumbar laminectomy and fusion ( $\leq 3$ levels). Spine (Phila Pa 1976) 40:E978-E985, 2015

15. Li ZJ, Fu X, Xing D, Zhang HF, Zang JC, Ma XL: Is tranexamic acid effective and safe in spinal surgery? A meta-analysis of randomized controlled trials. Eur Spine J 22:1950-1957, 2013

16. Liang J, Shen J, Chua S, Fan Y, Zhai J, Feng B, et al: Does intraoperative cell salvage system effectively decrease the need for allogeneic transfusions in scoliotic patients undergoing posterior spinal fusion? A prospective randomized study. Eur Spine J 24:270-275, 2015

17. Miao YL, Ma HS, Guo WZ, Wu JG, Liu Y, Shi WZ, et al: The efficacy and cost-effectiveness of cell saver use in instrumented posterior correction and fusion surgery for scoliosis in school-aged children and adolescents. PLoS One 9:e92997, 2014

18. Mirza AH, Aldlyami E, Bhimarasetty C, Thompson AG, Spilsbury J, Marks DS: The role of peri-operative cell salvage in instrumented anterior correction of thoracolumbar scoliosis: a case-controlled study. Acta Orthop Belg 75:8793, 2009

19. Moher D, Liberati A, Tetzlaff J, Altman DG: Preferred reporting items for systematic reviews and meta-analyses: the PRISMA statement. PLoS Med 6:e1000097, 2009
20. Mullis B, Fisk E, Weaver D, Zhao Q, Daggy J, Di Cesare PE: Anemia versus transfusion: does blood conservation increase the risk of complications? Am J Orthop 44:E11-E16, 2015

21. Oliveira JAA, Façanha Filho FAM, Fernandes FV, Almeida PC, de Oliveira VF, Lima Verde SR: Is cell salvage costeffective in posterior arthrodesis for adolescent idiopathic scoliosis in the public health system? J Spine Surg 3:2-8, 2017

22. Owens RK II, Crawford CH III, Djurasovic M, Canan CE, Burke LO, Bratcher KR, et al: Predictive factors for the use of autologous cell saver transfusion in lumbar spinal surgery. Spine (Phila Pa 1976) 38:E217-E222, 2013

23. Reitman CA, Watters WC III, Sassard WR: The Cell Saver in adult lumbar fusion surgery: a cost-benefit outcomes study. Spine (Phila Pa 1976) 29:1580-1584, 2004

24. Savvidou C, Chatziioannou SN, Pilichou A, Pneumaticos SG: Efficacy and cost-effectiveness of cell saving blood autotransfusion in adult lumbar fusion. Transfus Med 19:202206, 2009

25. Simpson MB, Georgopoulos G, Eilert RE: Intraoperative blood salvage in children and young adults undergoing spinal surgery with predeposited autologous blood: efficacy and cost effectiveness. J Pediatr Orthop 13:777-780, 1993

26. Triulzi DJ, Vanek K, Ryan DH, Blumberg N: A clinical and immunologic study of blood transfusion and postoperative bacterial infection in spinal surgery. Transfusion 32:517524,1992

27. Weiss JM, Skaggs D, Tanner J, Tolo V: Cell Saver: is it beneficial in scoliosis surgery? J Child Orthop 1:221-227, 2007

\section{Disclosures}

The authors report no conflict of interest concerning the materials or methods used in this study or the findings specified in this paper.

\section{Author Contributions}

Conception and design: all authors. Acquisition of data: T Cheriyan, J Cheriyan. Analysis and interpretation of data: all authors. Drafting the article: all authors. Critically revising the article: all authors. Reviewed submitted version of manuscript: all authors. Approved the final version of the manuscript on behalf of all authors: T Cheriyan. Statistical analysis: T Cheriyan, J Cheriyan. Administrative/technical/material support: T Cheriyan, J Cheriyan. Study supervision: T Cheriyan, Dua, Goldstein, Errico, Kumar.

\section{Correspondence}

Thomas Cheriyan: Augusta University, Augusta, GA. thomascheriyan@gmail.com. 